Soraya N. Joson, MD

Joman Q. Laxamana, MD

Department of Otorhinolaryngology

Head and Neck Surgery

East Avenue Medical Center, Philippines
Correspondence: Dr. Joman Q. Laxamana

Department of Otorhinolaryngology - Head \& Neck Surgery

6th Floor, East Avenue Medical Center, East Ave.

Diliman, Quezon City 1100

Philippines

Phone: (632) 89280611 local 324

Fax: (632) 34356988

Email: jqlaxamana@gmail.com

The authors declared that this represents original materia that is not being considered for publication or has not been published or accepted for publication elsewhere, in full or in part, in print or electronic media; that the manuscript has been read and approved by all the authors, that the requirements for authorship have been met by each author, and that each author believes that the manuscript represents honest work.

Disclosures: The authors signed disclosures that there are no financial or other (including personal) relationships, intellectua passion, political or religious beliefs, and institutional affiliations that might lead to a conflict of interest.

Presented at the Philippine Academy of Rhinology Antonio L. Roxas International Research Contest, December 1, 2017. Manila Hotel, One Rizal Park، Manila.

\title{
Air Pollution and Nasal Mucociliary Clearance Time among Urban and Rural Residents in Two Philippine Communities
}

\section{ABSTRACT}

Objective: To measure the nasal mucociliary clearance (NMC) time among adults residing in two Philippine communities with different air quality indices using the saccharin and methylene blue test.

\section{Methods:}

\section{Design: Cross-Sectional Study}

Setting: $\quad$ Diliman, Quezon City and Puerto Princesa, Palawan

Participantss: Fifty (50) participants, 25 residing in an urban city with fair air quality index and 25 residing in a rural province with good air quality index.

Results: The mean NMC time of the urban group was $22.15 \pm 12.68$ mins and was significantly longer than the NMC time of the rural group which was $5.29 \pm 2.87$ mins; $t(48)=6.643, p<0.0001$ ).

Conclusion: Increased air pollution may be associated with significant prolongation of nasal mucociliary clearance time among urban residents with fair quality air index compared to rural residents with good quality air index.

Keywords: nasal mucociliary clearance, naso mucociliary clearance time, air pollution, air quality index, saccharin test, methylene blue

Our world is undergoing a continuous wave of urban growth. As more people populate the cities and generate air pollution, its impact on the human respiratory system becomes a primary concern. The nose and sinuses protect the body against air pollution through the nasal mucociliary clearance (NMC), the process by which the ciliated nasal respiratory mucosa moves mucus, along with trapped particles or pathogens, from the nose to the pharynx where it is either swallowed or coughed. ${ }^{\text {? }}$

Any disruption of this dynamic process increases the risk of sinonasal and airway infection or dysfunction. ${ }^{2}$ Chronic rhinosinusitis can lead to destruction of large tracts of nasal cilia, prolonging the NMC time. ${ }^{3}$ Could chronic exposure to air pollution have a similar effect? 


\section{ORIGINAL ARTICLES}

With the thought that measuring the NMC time among urban and rural dwellers can provide insight on the relationship between air pollution levels and nasal dysfunction, this study sought to measure the nasal mucociliary clearance time among adults residing in two Philippine communities with different air quality indices using the saccharin and methylene blue test.

\section{METHODS}

With institutional ethics review board approval, this cross-sectional study was conducted in two settings. A residential area around a tertiary government hospital in Diliman, Quezon City with a population density of 17,759 residents/square $\mathrm{km}^{2}$ and a Fair Air Quality Index (AQI), was selected as the urban sampling location. A residential area around a primary health center in Puerto Princesa, Palawan with a population density of only 58 residents/square $\mathrm{km}^{2}$ and a Good AQI, was selected as the rural sampling location.

A single investigator performed random consecutive sampling of 50 adult Filipino resident volunteers, 25 from the urban site and 25 from the rural site. The participants did not belong to any single particular ethnic or tribal group. Previous and active smokers, asthmatics, those with a history of upper respiratory and sino-nasal disease within one month, and those with hypertension, diabetes and previous sinonasal surgeries were excluded from the study. Informed consent was obtained from all participants. All data was treated with strict confidentiality, deidentified and coded in compliance with the Data Privacy Act.

In each location, testing took place in the afternoons under similar ambient temperatures and sunny weather conditions (humidity was not measured). Each participant was seated in a well ventilated, nonairconditioned room. A solution of $10 \mathrm{ml}$ methylene blue and $1 \mathrm{gm}$ saccharine was pre-prepared for all participants. A single investigator who was also a trained otorhinolaryngologist performed all procedures to decrease bias and increase reproducibility.

For each participant, the investigator performed right anterior rhinoscopy using a headlight and a nasal speculum. An assistant placed one drop $(0.05 \mathrm{ml})$ of the solution on a commercially available metal ear loop and the investigator applied it on the medial surface of the inferior turbinate, $1 \mathrm{~cm}$ posterior from its anterior tip. No other substance such as saline sprays, topical anesthesia or decongestant was used and the procedure was only performed once per participant. The participants were instructed to swallow every 30 seconds and were prohibited from sniffing, sneezing, coughing, eating and drinking. The participants were instructed to immediately report the moment they perceived a sweet taste. The investigator then recorded the time elapsed from placement of the saccharin/methylene blue solution to the reported perception of sweet taste as the NMC time. The reported perception was subsequently confirmed by noting the presence of methylene blue streaks on the posterior pharyngeal wall.

\section{RESULTS}

After exclusions, a total of 50 participants successfully completed the tests and were included in data analysis; 25 each in the urban and rural groups. Nine (9) males and 16 females aged 24-45 years old (mean of 26.28 years) comprised the urban group while 15 males and 10 females aged 21-35 years old (mean of 30.96 years) comprised the rural group. Chi-square test showed no significant difference between the two groups in terms of sex distribution ( $\mathbf{X} 2(1)=2.885, p=0.089$ ). Similarly, unpaired t-test showed no significant difference between the two groups in terms of mean age ( $t(48)=2.42, p=0.575$ ), with both mean ages within the young adult range.

All participants were able to comply with test instructions and were confirmed to have the dye visible in their posterior pharyngeal wall following the reported perception of sweet taste. The NMC times ranged from 7 to 47 mins (mean of $22.56 \pm 12.68$ mins) among urban participants and from 1.27 to 15 mins (mean of $5.29 \pm 2.87$ mins) among rural participants. Using unpaired t-tests, the mean NMC time of the urban group was significantly longer than the rural group $(\mathrm{t}(48)=$ $6.643, p<0.0001)$.

All data was analyzed using IBM SPSS Statistics version 25 (IBM Company, Armonk, NY, USA).

\section{DISCUSSION}

Our study showed a significant prolongation of NMC time among residents of a moderately polluted urban city as opposed to those living in an unpolluted rural area in the Philippines. A similar local study by Ramos et al. ${ }^{4}$ in 1999 showed that urban Metro Manila residents have significantly longer mucus transport time (10-15mins) than rural Camarines Norte residents (5-10mins), but air quality data was not measured. Several studies have shown that the normal adult NMC time is 5-14 minutes. ${ }^{5,6}$ In adults with allergic rhinitis and asthma, the NMC time is usually within 18 to 30 minutes while in those with chronic rhinosinusitis, it may be delayed by more than an hour. ${ }^{7}$ By this definition, several participants from the urban group had pathologically prolonged NMC times and further investigation on their nasal epithelial morphology would be noteworthy (chronic rhinosinusitis was not an exclusion criterion, and other exclusion criteria were based on history alone).

Despite common knowledge of the negative health effects of air pollution, there is little evidence that urban levels of pollution can damage nasal ciliated epithelial cells in humans. To our knowledge, 
ORIGINAL ARTICLES

there are only a few studies on the effect of some components of outdoor air pollution. One such study showed that cigarette smokers had a significantly prolonged NMC time than lifelong non-smokers. ${ }^{8}$ Cigarette smoke exposure was also correlated with significantly slower ciliary beat frequency. ${ }^{9}$ Outdoor pollutants such as sulfur dioxide, nitrogen dioxide and ozone could cause ciliary stasis and ciliated cell damage but only in high concentrations not seen in urban air pollution. ${ }^{10}$ Only studies in lambs and rats demonstrate mucosal hypersecretion and ultrastructural ciliary damage after exposure to urban levels of air pollution. ${ }^{11,12}$ Unfortunately, we found no similar morphologic studies performed on humans.

Although its impact on NMC is poorly understood, air pollution is known to significantly increase the risk of lung cancer ${ }^{13}$ and many countries have implemented air quality control laws. In the Philippines, Republic Act 8749 or the Philippine Clean Air Act of 1999 mandated the establishment of continuous air quality monitoring systems, standardization of an Air Quality Index (AQI) and creation of associated health guidelines. ${ }^{14}$ Our study utilized real-time pollution data and AQI standards from the government website (air.emb.gov.ph). (Table 1)

The saccharin test is the simplest and most inexpensive technique that can be performed in numerous subjects to measure NMC time. ${ }^{15}$ To increase the accuracy of results, we added methylene blue to the saccharine solution as an objective confirmatory test of mucus passage

Table 1. Air Quality Index breakpoints as mandated by Philippine Republic Act 8749

\begin{tabular}{|c|c|c|c|c|c|c|c|}
\hline Pollutant & $\begin{array}{c}\text { Unit, } \\
\text { Averaging } \\
\text { Time }\end{array}$ & Good & Fair & $\begin{array}{l}\text { Unhealthy } \\
\text { for } \\
\text { sensitive } \\
\text { group }\end{array}$ & $\begin{array}{c}\text { Very } \\
\text { unhealthy }\end{array}$ & $\begin{array}{c}\text { Acutely } \\
\text { unhealthy }\end{array}$ & $\begin{array}{l}\text { Emer- } \\
\text { gency }\end{array}$ \\
\hline TSP & $\begin{array}{c}\mu \mathrm{g} / \mathrm{Nm} 3 \\
24-\mathrm{hr}\end{array}$ & $0-80$ & $81-230$ & $231-349$ & $350-599$ & $600-899$ & $\begin{array}{l}900 \text { and } \\
\text { greater }\end{array}$ \\
\hline PM10 & $\begin{array}{c}\mu \mathrm{g} / \mathrm{Nm} 3 \\
24-\mathrm{hr}\end{array}$ & $0-54$ & $55-154$ & $155-254$ & $255-354$ & $355-424$ & $425-504$ \\
\hline $\mathrm{SO} 2$ & $\begin{array}{l}\text { ppm, } \\
24-h r\end{array}$ & $\begin{array}{l}0.00- \\
0.34\end{array}$ & $\begin{array}{l}0.035- \\
0.144\end{array}$ & $\begin{array}{l}0.145- \\
0.224\end{array}$ & $\begin{array}{l}0.225- \\
0.304\end{array}$ & $\begin{array}{c}0.305- \\
0.604\end{array}$ & $\begin{array}{l}0.605- \\
0.804\end{array}$ \\
\hline \multirow{2}{*}{$\mathrm{O} 3$} & ppm, 8-hr & $\begin{array}{l}0.000- \\
0.064\end{array}$ & $\begin{array}{c}0.065- \\
0.084\end{array}$ & $\begin{array}{l}0.085- \\
0.104\end{array}$ & $\begin{array}{c}0.105- \\
0.124\end{array}$ & $\begin{array}{l}0.125- \\
0.374\end{array}$ & a \\
\hline & ppm, 1-hr & - & - & $\begin{array}{l}0.125- \\
0.164\end{array}$ & $\begin{array}{l}0.165- \\
0.204\end{array}$ & $\begin{array}{l}0.205- \\
0.404\end{array}$ & $\begin{array}{c}0.405- \\
0.504\end{array}$ \\
\hline $\mathrm{CO}$ & ppm, 8-hr & $0.0-4.4$ & $4.5-9.4$ & $9.5-12.4$ & $12.5-15.4$ & $15.5-30.4$ & $\begin{array}{c}30.5- \\
40.4\end{array}$ \\
\hline $\mathrm{NO} 2$ & ppm, 1-hr & b & $b$ & $b$ & b & $0.65-1.24$ & $\begin{array}{l}1.25- \\
1.64\end{array}$ \\
\hline
\end{tabular}

TSP $=$ Total Suspended Particulates, PM10 $=$ particulate matter 10 micrometers or less in diameter, $\mathrm{SO} 2=$ Sulfur Dioxide, $\mathrm{O} 3=$ Ozone, $\mathrm{CO}=$ Carbon Monoxide, $\mathrm{NO} 2=$ Nitrogen Dioxide

$\mathrm{a}=$ When 8-hour $\mathrm{O} 3$ concentrations exceed $0.374 \mathrm{ppm}, \mathrm{AQI}$ values of 301 or higher must be calculated with 1-hour $\mathrm{O} 3$ concentrations.

$\mathrm{b}=\mathrm{NO} 2$ has no 1 -hour term to the pharynx. Methylene blue has been safely used in the monitoring of mucus flow inside the maxillary sinus ${ }^{16}$ and bronchi. ${ }^{17}$ To the best of our knowledge, this is the first study to use combined saccharin and methylene blue in evaluating NMC time. Further research may confirm our experience with this combination.

In conclusion, our study suggests that among urban residents with fair quality air index compared to rural residents with good quality air index, air pollution may be associated with nasal mucociliary disruption. However, its pathophysiologic mechanisms need more investigation. In future studies, measurement of NMC time along with ciliary beat frequency, documentation of cellular damage and monitoring of long term disease outcomes could shed more light on the definite impact of air pollution on the nasal mucociliary function.

\section{REFERENCES}

1. Delong PA, Kotloff RM. An overview of pulmonary host defense. Semin Roentgenol. 2000;35(2):118-23. doi: 10.1053/ro.2000.6150. PubMed PMID: 10812649.

2. Yasar M, Sutbeyaz MY, Sakat MS, Kilic K. Evaluation of the effects on nasal mucociliary clearance of various nasal solutions applied topically in patients with sinusitis. Med-Science. 2018;7(1):1-4 doi:10.5455/medscience.2017.06.8655.

3. Ramos RP, Lagman VC, Campomanes, BS. A Comparison of the Mucus Transport Time between Filipinos Living in Urban and Rural Areas. Philipp J Otolaryngol Head Neck Surg. 1999 JulSept;14(3):2-6.

4. Birdi SM, Singh S, Singh A. Mucociliary clearance in chronic sinusitis. Indian J Otolaryngol Head Neck Surg. 1998 Jan; 50(1):15-9. doi: 10.1007/BF02996761. PubMed PMID: 23119370; PubMed Central PMCID: PMC3451257.

5. Karja J, Nuutinen J, Karjalainen P. Radioisotopic Method for Measurement of Nasal Mucociliary Activity. Arch Otolaryngol Head Neck Surg. 1982 Jan;108(2):99-101. doi: 10.1001/ archotol.1982.00790500035008. PubMed PMID: 6460494.

6. Pandya VK, Tiwari RS. Nasal mucociliary clearance in health and disease. Indian J Otolaryngol Head Neck Surg. 2006 Oct 1;58(4):332-4. doi: 10.1007/BF03049581. PubMed PMID: 23120337 PubMed Central PMCID: PMC3450371.

7. Stanley P, Wilson R, Greenstone M, Mackay I, Cole P. Abnormal nasal mucociliary clearance in patients with rhinitis and its relationship to concomitant chest disease. Brit J Dis Chest. 1985;79:77-82. doi: 10.1016/0007-0971(85)90010-5. PubMed PMID: 3986114.

8. Stanley PJ, Wilson R, Greenstone MA, MacWilliam L, Cole PJ. Effect of cigarette smoking on nasal mucociliary clearance and ciliary beat frequency. Thorax. $1986 \mathrm{Jul}$ 1;41(7):519-23. doi: 10.1136/ thx.41.7.519. PubMed PMID: 3787531; PubMed Central PMCID: PMC460384.

9. Agius AM, Smallman LA, Pahor AL. Age, smoking and nasal ciliary beat frequency. Clin Otolaryngol Allied Sci. 1998 Jun;23(3):227-30. doi: 10.1046/j.1365-2273.1998.00141.x. PubMed PMID: 9669071.

10. Pedersen M. Ciliary activity and pollution. Lung. 1990 Dec 1;168(1):368-76. doi: 10.1007/ bf02718154. PubMed PMID: 2117139.

11. Gulisano M, Marceddu S, Barbaro A, Pacini A, Buiatti E, Martini A, Pacini P. Damage to the nasopharyngeal mucosa induced by current levels of urban air pollution: a field study in lambs. Eur Respir J. 1997 Mar 1;10(3):567-72. PubMed PMID: 9072986.

12. Saldiva PH, King M, Delmonte VL, Macchione M, Parada MA, Daliberto ML, Sakae RS, Criado PM, Parada PL, Zin WA, Böhm GM. Respiratory alterations due to urban air pollution: an experimental study in rats. Environ Research. 1992 Feb 1;57(1):19-33. doi: 10.1016/s0013-9351(05)80016-7. PubMed PMID: 1371246.

13. Chen G, Wan X, Yang G, Zou X. Traffic-related air pollution and lung cancer: A meta-analysis. Thorac cancer. 2015 May;6(3):307-18. doi: 10.1111/1759-7714.12185. PubMed PMID: 26273377. PubMed Central PMCID: PMC4448375.

14. Republic of the Philippines, Department of Environment and Natural Resources, Environmental Management Bureau [Internet]. National Air Quality Status Report. [cited 2017 October 2] Available from: https://emb.gov.ph/wp-content/uploads/2018/08/National-Air-Quality-StatusReport-2008-2015.pdf

15. Stanley P, MacWilliam L, Greenstone M, Mackay I, Cole P. Efficacy of a saccharin test for screening to detect abnormal mucociliary clearance. Brit J Dis Chest . 1984 Jan 1;78:62-5. PubMed PMID: 6691910.

16. Griffa A, Berrone M, Boffano P, Viterbo S, Berrone S. Mucociliary function during maxillary sinus floor elevation. J. Craniofac. Surg. 2010 Sep 1;21(5):1500-2. doi: 10.1097/SCS.0b013e3181 ef2be9. PubMed PMID: 20818241.

17. Keller C, Brimacombe J. Bronchial mucus transport velocity in paralyzed anesthetized patients: a comparison of the laryngeal mask airway and cuffed tracheal tube. Anesth Analg. 1998 Jun 1;86(6):1280-2. doi: 10.1097/00000539-199806000-00028. PubMed PMID: 9620520. 